\title{
EFFECT OF SOME NATURAL PLANTS OILS ON THE GROWTH OF SOME PATHOGENIC BACTERIA
}

\author{
Alsanussi Ahmed Ali Albi \\ Faculty of Medical Technology - Surman, Sabratha University
}

\begin{abstract}
This study aimed to determine the influence some of essential oils (black seed oil, garlic oil, and thyme oil on the Growth of some Pathogenic Bacteria (psychotropic bacterial, E.coli, Salmonella and Staphylococcus aureus.
\end{abstract}

The results showed:-

1- All treatments had positive effect on the bacterial growth; the treatment of black seed was the highest effective when compared with other treatments.

2- Changes of psychrotrophic bacterial count in minced meat treated with essential oils during storage at $4^{\circ} \mathrm{C}$ for 20 day.

Microorganisms that grow in food at refrigeration temperature have usually been called psychotropic. Many psychotropic bacteria when present in large numbers can cause a variety of off-flavors as well as physical and defects in foods, Psychrophilic bacteria counts in all treatments at zero time were similar, but there is a significant increase in control sample to $10^{7} \log \mathrm{CFU} / \mathrm{gm}$. At the end of storage periods ( $\left.\mathrm{p} \geq 0.05\right)$ Psychotropic bacteria counts reduced with addition of essential oils compared with control samples.

3- Changes of E. coli count in minced meat treated with essential oils during storage at $4^{\circ} \mathrm{C}$ for 20 day.

Although the total bacterial count was used in bacteriological examination to reflect the hygienic quality, however, it is evident that coliform group count is considered of much greater value in assessing its quality. It was found that control sample had significantly ( $\mathrm{p} \geq 0.05$ ) difference the higher counts $E$. coli when compared to other treatments which formulated with essential oils at levels 0.50 and $0.75 \%$ and $1 \%$ at zero time and at end of storage periods. Essential oil of black seeds at level $1 \%$ was more active of inhibiting effect against coliform group bacteria, which disappear after 10 days of storage period compared with other essential oils. Also, E. coli group disappeared in most minced meat samples formulated with essential oil at level $1 \%$ at 15 and 20 days.

4- Changes of Salmonella counts in minced meat treated with essential oils during storage at $4^{\circ} \mathrm{C}$ for 20 day.

Salmonella is now established, as one of the most important causes of food - borne illness at worldwide. It was found that control sample had significant $(p \geq 0.05)$ difference from the higher counts of Salmonella when compared to other treatments which formulated with essential oils at levels 0.50 and $0.75 \%$ and $1 \%$ at end of 
storage periods. Essential oil of black seed at level $1 \%$ was more active of inhibiting effect against Salmonella group bacteria, which disappeared after 5 days of storage period compared with other essential oils. Also, it could be noticed that Salmonella group disappeared from most minced beef samples formulated with essential oil at levels $0.75 \%$ and $1 \%$ after 10 and 15 days.

5- Changes of Staphylococcus Aureus counts in minced meat treated with essential oils during storage at $4{ }^{\circ} \mathrm{C}$ for 20 day:

The results showed that Staphylococcus aureus counts increased in control sample, so the Staphylococcus aureus count at zero time was $3.310^{2} \mathrm{CFU} / \mathrm{g}$, but reached to 5.4 $10^{3} \mathrm{CFUI} / \mathrm{g}$ at the end of storage period.

It could be noticed that Staphylococcus aureus counts were significantly $(\mathrm{p} \geq 0.05)$ decreased during storage time in minced meet sample contained essential oil of black seeds at level $0.75 \%$ and $1 \%$. Staphylococcus aureus counts in these samples were less than that in control sample. Meanwhile, after storage for 5 days, Staphylococcus aureus disappeared from minced meet samples contained black seeds essential oil at level $1 \%$.

Keywords: essential oils, contamination, pathogenic bacteria.

\section{Introduction}

Essential oils (Eos) are aromatic oily liquids obtained from plant material. Extracts from, Thyme, Garlic and black seeds are some of the Eos that have been used to improve the sensory characteristics and extend the shelf-life of foods (Burt, 2004). A number of Eos and some of their components have been reported to appear antimicrobial activity against a wide range of spoilage and pathogenic bacteria. The antimicrobial properties of Eos are mainly attributed to their phenolic compounds, i.e. carvacrol and thymol and to terpenes (Burt, 2004). Many naturally occurring compounds found in plants, herbs, and spices have been shown to possess antimicrobial functions and serve as a source of antimicrobial agents against food-borne pathogens (Brul and Coote, 1999).

Plant extracts represent a rich potential source of alternative and environmentally acceptable control agents for infectious organisms due to their antimicrobial properties. Plants possess essential oils, which could be utilized for killing microorganisms (Ahmed et al., 2011).

Food processors and consumers have expressed a desire to reduce the use of synthetic chemical additives in food preservation. Recently, there has been a considerable interest in extracts and essential oils from common culinary herbs, spices and aromatic plants characterized by a notable antimicrobial activity. Such substances could be used to delay or inhibit the growth of pathogenic and/or toxin producing microorganisms in foods (Marino et al., 2001). This growing interest is emphasized by the fact that food-borne diseases are still a major problem in the world, even in well developed countries (Mead et al., 1999). There are many types of bacteria considered pathogenic bacteria such as Escherichia coli; 
Clostridium perfringens; Staphylococcus aureus; Listeria monocytogenes; Campylobacter jejuni/coli; Escherichia coli 0157:H7; and Salmonella. These bacteria can cause diseases to human so that this study will evaluate the effect of Eos on the growth of some pathogenic bacteria.

\section{Mode of Action of Essential Oils}

The antimicrobial and antioxidant properties of essential oils have been recognized for many years, and their preparations have found applications as naturally occurring antimicrobial and antioxidant agents in the field of pharmacology, pharmaceutical botany, phytopathology, medical, and clinical microbiology, food preservation, and so on, (Burt 2004). The essential oil and various extracts preparations that possess antimicrobial and/or antioxidant activities have been the subject of many investigations resulting in the screening of a wide variety of plant species, and have revealed structural unique and biologically active compounds. However, less attention was paid to the activity of their main components in essential oils tested. The main advantage of new natural agents is that they do not present the "antibiotic resistance," a phenomenon commonly countered with the long-term use of antibiotics. The antimicrobial and antioxidant activities of essential oils are assigned to a number of small terpenoids and phenolic compounds (thymol, carvacrol and eugenol), which also in pure form demonstrate high antibacterial and antioxidant activities (Troy and Kerry 2010).

Antioxidants are compounds or systems that delay autoxidation By inhibiting formation of free radicals or by interrupting propagation of the free radical by one (or more) of several mechanisms: scavenging species that initiate peroxidation, chelating metal ions such that they are unable to generate reactive species or decompose lipid peroxides, quenching $\mathrm{O} 2$ preventing formation of peroxides, breaking the autoxidative chain reaction and reducing localized $\mathrm{O}$ concentrations. Antioxidants used in the food industry can be classified into two types: natural and synthetic. They can also be classified as type I and type II based on their oxidation inhibition mechanism. The criterion for choosing an antioxidant depends upon the kind of food, the potency of the antioxidant, storage temperature of the food, and the fat content. Some of the commonly used antioxidants are a-tocopherol, ascorbic acid, butylated hydroxylanisole (BHA), and butylated hydroxytoluene (BHT) (Tiwari et al., 2009).

Antioxidant is a substance that delays oxidation by inhibiting initial free radical formation or by preventing them from producing more free radicals which can perpetuate the reaction (lopes et al., 2005).

The major antioxidative plant phenolic can be divided into 4 general groups: phenolic acids (gallic, protochatechuic, caffeic and rosmarinic acids), phenolic diterpenes (carnosol and carnosic acid), flavonoids (quercetin and catechin), and volatile oils (eugenol, carvacrol, thymol and menthol) Phenolic acids generally act as antioxidants by trapping free radicals; flavonoids can scavenge free radicals and chelate metals as well (Geldof and Engeseth, 2002). 


\section{Effect of Materials and Methods.}

\section{Essential Oil Samples}

The essential oils of black seeds oil, thyme oil and garlic oil were obtained from National Research Center at Giza, Egypt.

Studied bacteria was isolated from minced meat sold in local market of some cities in western Libya.

\section{Culture Media for Microbiological Assay}

\section{Media Used for Determination of Total Bacterial Counts}

Nutrient agar medium (American Public Health Association (Difco, 1984) was used for the determination of total bacterial count.

Composition of the media was as follows:

$\begin{array}{ll}\text { Bacto - beef extract } & 3.0 \mathrm{~g} . \\ \text { Bacto - peptone } & 5.0 \mathrm{~g} . \\ \text { Bacto - agar } & 15.0 \mathrm{~g} . \\ \text { Distilled water up to } & 1000.0 \mathrm{ml} . \\ \text { pH of medium } & 7.0 \pm 0.2\end{array}$

Mix thoroughly and heat to boiling to dissolve the ingredients. Dispense into flasks and autoclave for $15 \mathrm{~min}$ at $121^{\circ} \mathrm{C}$.

\section{Media Used for Determination of Staphylococcus Aureus}

Manitol salt agar medium was used to count Staphylococcus aureus according to (Difco, 1984). It's composition as follows:

$\begin{array}{ll}\text { Proteose peptone No.3 } & 10.0 \mathrm{~g} \\ \text { Bacto-beef extract } & 100 \mathrm{~g} \\ \text { Bacto-mannitol } & 10.00 \mathrm{~g} \\ \text { Sodium chloride } & 75.00 \mathrm{~g} \\ \text { Bacto-agar } & 15.00 \mathrm{~g} \\ \text { Bacto - phenol red } & 0.025 \mathrm{~g} \\ \text { Distilled water up to } & 1000.0 \mathrm{ml} \\ \text { PH of medium } & 7.4 \pm 0.20\end{array}$

These ingredients were mixed thoroughly, boiled to dissolve them and then dispensed into flasks and autoclaved at $121^{\circ} \mathrm{C}$ for $15 \mathrm{~min}$. 


\section{Media Used for Determination of Coliform Group Bacteria}

MacConkey agar medium (Difco, 1984) was used for counting the coliform group bacteria. Its composition was as follows:

$\begin{array}{ll}\text { Bacto - peptone } & 17.0 \mathrm{~g} . \\ \text { Proteose peptone } & 3.0 \mathrm{~g} . \\ \text { Bacto - lactose } & 10.0 \mathrm{~g} . \\ \text { Bacto - bile salts } & 1.5 \mathrm{~g} . \\ \text { Sodium chloride } & 5.0 \mathrm{~g} . \\ \text { Bacto - neutral red } & 0.03 \mathrm{~g} . \\ \text { Bacto - crystal violet } & 0.001 \mathrm{~g} . \\ \text { Bacto - agar } & 13.5 \mathrm{~g} . \\ \text { Distilled water up to } & 1000.0 \mathrm{ml} . \\ \text { Final pH } & 7.1 \pm 0.2\end{array}$

Mixed thoroughly and heat to boiling to dissolve the ingredients. Dispense in flask and autoclave for $15 \mathrm{~min}$. at $121^{\circ} \mathrm{C}$.

\section{Media Used for Salmonella}

The salmonella agar medium (FAO, 1979) used as a selective plating media. Its composition was as follows:-

$\begin{array}{ll}\text { Beef extract } & 5.0 \mathrm{~g} . \\ \text { Peptone } & 5.0 \mathrm{~g} . \\ \text { Lactose } & 10.0 \mathrm{~g} . \\ \text { Bile salts } & 5.5 \mathrm{~g} . \\ \text { Sodium citrate } & 10.0 \mathrm{~g} . \\ \text { Sodium thiosulphate } & 8.5 \mathrm{~g} . \\ \text { Ferric citrate } & 1.0 \mathrm{~g} . \\ \text { Brillient green } & 0.00033 \mathrm{~g} . \\ \text { Neutral red } & 0.025 \mathrm{~g} . \\ \text { Agar } & 12.0 \mathrm{~g} . \\ \text { Distilled water } & 1000.0 \mathrm{ml} . \\ \text { Final pH } & 7.0 \pm 0.2\end{array}$

Mixed thoroughly until homogeneous, then heated with occasional agitation and boiled until the ingredient dissolve. Cooled to $45-50^{\circ} \mathrm{C}$ and pour $10 \mathrm{ml}$ into petri dishes. Do not autoclave.

\section{Isolation of Some Pathogenic Bacteria}

\section{Staphylococcus Aureus Count}

Staph. aureus bacteria was determined according to the method described by (APHA., 1976 and Difco Manual, 1984) using vogal Jonson media plus $1 \mathrm{ml}$ potassium tellurite 
solution $1 \%(\mathrm{w} / \mathrm{v})$ to each $100 \mathrm{ml}$ of sterilize media which mixed well before pouring in the plates. The plates were incubated at $37^{\circ} \mathrm{C}$ for $24 \mathrm{hr}$.

\section{Coliform group Bacteria Count}

Coliform group bacteria were determined using MacConkey agar medium according to the procedures described by A.P.H.A (1976) and Difco (1984). The plates were incubated at $37^{\circ} \mathrm{C}$ for $24 \mathrm{hr}$.

\section{Isolation of Salmonella}

The presence or absence of salmonella was determined according to the method described by FAO (1979); salmonella agar plates were incubated at $35^{\circ} \mathrm{C}$ for $24 \mathrm{hr}$. Salmonella appeared as black colonies, some of them with metallic sheet.

\section{Preparation of Minced Beef Treated with Essential Oils and Spices Powder for} Analysis

Minced beef was mixed in sterile mixer with $0.25,0.5,0.75 \%$ and $1 \%$ essential oils of their weight, the samples were divided into two groups; one group was treated with 0.25 and $0.5 \%, 0.75 \%$ and $1 \%$ essential oils, and the second group was kept as a control group. Each sample was packed in polyethylene bags and stored at $4^{\circ} \mathrm{C} \pm 1$, and all analysis was conducted at intervals of $0,10,15$ and 20 days.

\section{Results and Discussion}

\section{Antimicrobial Activity of Thyme Essential Oil}

The antimicrobial activity of Thyme essential oil at different concentrations was determined by the well agar diffusion method against different isolated bacteria. The diameters of inhibition zones were measured and taken as an indicator of the antimicrobial effect (inhibitory activity). Results are shown in Table (1). Pointed to thyme essential oil were inhibited Gram-negative bacteria in higher degree more than the Gram-positive bacteria at concentration $0.75-1 \% \mathrm{mg} / \mathrm{ml}$. In addition, results showed that Escherichia coli O157:H7, Salmonella typhi and Staphylococcus aureus were more resistant Thyme essential oil at low concentrations $(.025-0.50 \% \mathrm{mg} / \mathrm{ml})$. These results are in good agreement with those obtained by Fridman et al.,(2002) and Pasque et al. (2005) they showed that concentrations of Thyme essential oil for Gram-negative bacteria was lower than Gram-positive bacteria. Occasionally, concentration extension of essential oil recorded the highest antimicrobial activity. According to essential oil, the antimicrobial activity of Thyme essential oil is assigned to be a number of terpenoid ( $\alpha$-Terpinene, $\gamma$ Terpinene and Terpinolene) which also in pure from have been shown to exhibit antibacterial or antifungal activities Conner, (1993). 
Table (1): Diameters of inhibition zones $(\mathrm{mm})$ of Thyme essential oil against isolated microorganisms:

\begin{tabular}{|c|c|c|c|c|c|c|}
\hline Concentrations $2(\mathrm{mg} / \mathrm{ml})$ & \multicolumn{6}{|c|}{ Diameters of inhibition zones (mm) } \\
\hline 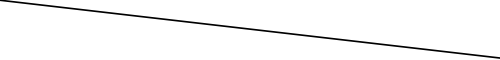 & Control & 0.25 & 0.5 & 0.75 & 1 & 2 \\
\hline Escherichia coli & 0.0 & 0.0 & 0.0 & 12 & 14 & 16 \\
\hline Salmonella & 0.0 & 0.0 & 0.0 & 10 & 12 & 14 \\
\hline Staphylococcus aureus & 0.0 & 0.0 & 0.0 & 0.0 & 0.0 & 0.0 \\
\hline
\end{tabular}

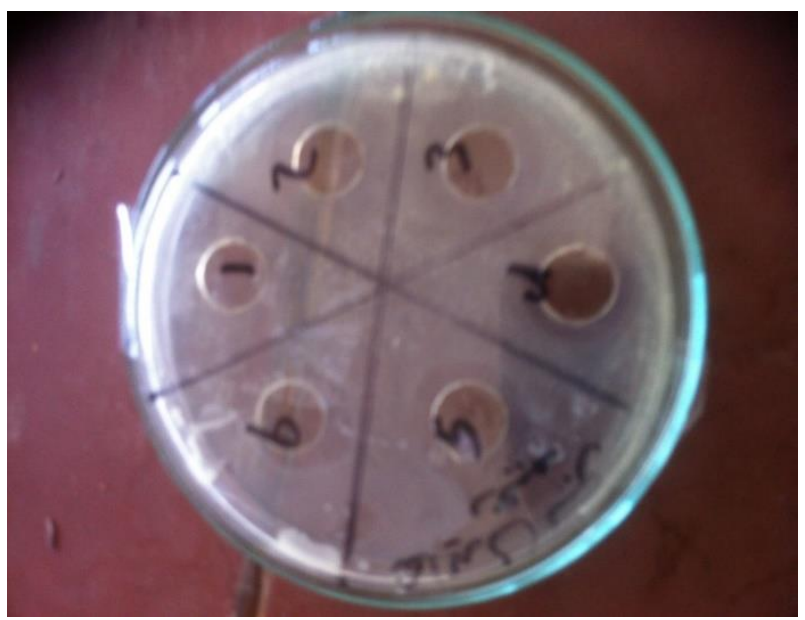

Figure (1): Inhibition zones (mm) of thyme essential oil against microorganisms

\section{Antimicrobial Activity of Garlic Essential Oil}

The anti-bacterial agent of Garlic essential oil, is effective against many more gram negative and gram positive bacteria like Helicobacter pylori, E.coli, Lactobacillus caseiand that this effect is sourced from allicin inside it (Cellini et al. (1996) and Lemar et al. (2005)).

It is also declared that components including sulphur in garlic and also bioflavonoids like quercetin and cyanidin in it have great value in preventing diseases

and infections. It's revealed that active substances like allistatin I and allistatin II in garlic are powerful agents against staphylococcus and E.coli bacteria (Baytop, 1999; Ayaz and Alpsoy, 2007; Ankri and Mirelman, 1999; Hanafyet al. (1991) and Yoshida et al. (1998)).

Data presented in Table (2) shows the antimicrobial effect of garlicessential oil at variable concentrations against different tested microorganisms expressed as the diameters of inhibition zones (mm). The all tested microorganisms exhibited sensitive to high 
concentrations of Garlic essential oil. It could be noticed that the microbial spectra were decreased with increasing the concentrations of Garlicessential oil. The

inhibitory effect of Garlic essential oil might be attributed to chemical composition of Garlic essential oil which contained gamma-Terpinene, Limonene, Camphor, $\alpha$-pinene, $\beta$ pinene and Camphene. These results are in agreement with those obtained by (Domokos, et al., (1997) and Abd El- Qader, (2003)).

Table (2): Diameters of inhibition zones ( $\mathrm{mm}$ ) of Garlic essential oil against microorganisms

\begin{tabular}{|l|l|l|l|l|l|c|}
\hline \multicolumn{1}{|c|}{$\begin{array}{c}\text { Concentrations } \\
\text { Microorganisms }\end{array}$} & \multicolumn{5}{c|}{ Diameters of inhibition zones (mm) } \\
\cline { 2 - 8 } & Control & $\mathbf{0 . 2 5}$ & $\mathbf{0 . 5}$ & $\mathbf{0 . 7 5}$ & $\mathbf{1}$ & $\mathbf{2}$ \\
\hline Escherichia coli & 0.0 & 0.0 & 0.0 & 0.0 & 10 & 12 \\
\hline Salmonella & 0.0 & 0.0 & 0.0 & 0.0 & 12 & 14 \\
\hline Staphylococcus aureus & 0.0 & 0.0 & 0.0 & 0.0 & 10 & 12 \\
\hline
\end{tabular}

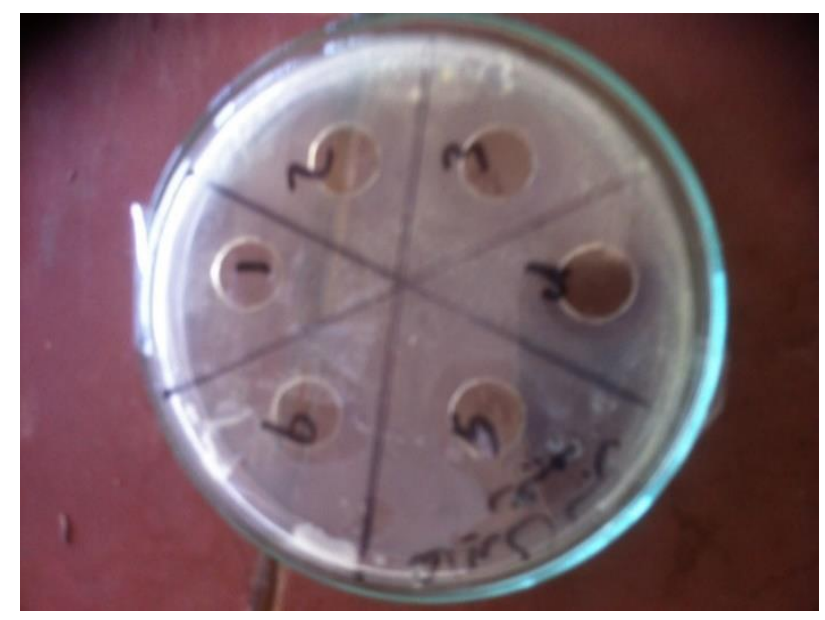

Figure (2): Inhibition zones ( $\mathrm{mm}$ ) of Garlic essential oil against microorganisms

\section{Antimicrobial Activity of Black Seeds Essential Oil}

Black seeds (black cumin, Nigella sativa) are herbaceous plant growing in Asian and Mediterranean countries. Black seeds oil or extract has been used for thousands of years as a spice, condiment, carminative, food preservative, as well as a protective and curative treatment for numerous disorders in traditional and Indian folk medicine (El-Sayed et al.,2001 and Merfortet al., 1997). The black seeds contain 36-38\% fixed oil, with proteins, alkaloids, saponins, and essential oils making up rest of the composition (Burtis and Bucar, 2000). Although black seeds extract or oil have been reported to possess antimicrobial activity (Morsi, 2000), antioxidant activity (Burtis and Bucar, 2000. Burtis and Bucar, 2000) showed that the alcoholic extract of Nigella sativa seeds had inhibitory effect on E.coli, Saureus, whilst the aqueous extract was inactive. Due to the increased resistance of bacterial pathogens to commercially used antibiotics and the growing interest in herbal 
medicine, (FazlyBazzazet al., 2002) investigated the antibacterial activity of Nigella sativa in mice infected with Staphylococcus aureus and E.coli. They found that the total extract of N. sativa seeds in methanol and chloroform and its essential oil has antibacterial activity on gram positive and gram negative organisms tested. (Morsi 2000) examined different crude extracts of Nigella sativa for antimicrobial effectiveness against different bacterial isolates. These isolates showed multiple resistances against antibiotics, especially the gram negative ones. Crude extracts of Nigella sativa showed a promising effect against some of the tested organisms. He mentioned that gram-negative isolates were affected more than the gram-positive ones. The antimicrobial activity of Nigellasativa essential oil at 2,5,10,15,20 and $25 \mathrm{mg} / \mathrm{ml}$, different concentrations was determined by the well agar diffusion method against isolated bacteria. The diameters of inhibition zones were measured and taken as an indicator of the antimicrobial effect (inhibitory activity). Results are in Table (3) clearly shown that of Nigellasativa essential oil exhibited antimicrobial activity against most tested microorganisms. It showed high activity against Escherichia coli O157:H7, Staphylococcus aureus and Salmonella sp. Occasionally, it could be noticed that microbial spectra were decreased with increasing the concentrations of essential oils. The inhibitory effect of Nigella sativa essential oil might be attributed to chemical composition of Nigellasativa essential oil which contained p-Cymene, Sabinene, Myrcene, $\alpha$-Terpinene and $\alpha$-Thujene. These results are in agreement with those obtained by Salman et al., (2008), who found that black seeds were long used for preventing, or even curing infectious conditions, inhibit growth of pathogenic bacteria. In addition, Hannan, et al., (2008) Nigellasativa extract was extensively studied for its antimicrobial activity against a wide range of bacterial, fungal and parasitic organisms. Morsi, (2000) examined the antimicrobial activity of the volatile oil of Nigella sativa and the results indicated that the compound was of high antimicrobial activity against gram positive (Bacillus subtilis, Straphylococcus aureus, and Micrococcus lysodeikticus), gram negative bacteria (E.coli, S typhiand Pseudomonas aeruginosa) and yeasts, but has no sporicidal activity.

Table (3): Diameters of inhibition zones $(\mathrm{mm})$ of black seeds essential oil against isolated microorganisms

\begin{tabular}{|l|l|l|l|l|l|c|}
\hline \multicolumn{1}{|c|}{$\begin{array}{c}\text { Concentrations } \\
(\mathbf{m g} / \mathbf{m l})\end{array}$} & \multicolumn{5}{|c|}{ Diameters of inhibition zones (mm) } \\
\cline { 2 - 8 } Microorganisms & Control & $\mathbf{0 . 2 5}$ & $\mathbf{0 . 5}$ & $\mathbf{0 . 7 5}$ & $\mathbf{1}$ & $\mathbf{2}$ \\
\hline Escherichia coli & 0.0 & 0.0 & 15 & 17 & 19 & 20 \\
\hline Salmonella & 0.0 & 0.0 & 16 & 18 & 20 & 22 \\
\hline Staphylococcus aureus & 0.0 & 0.0 & 14 & 16 & 18 & 20 \\
\hline
\end{tabular}




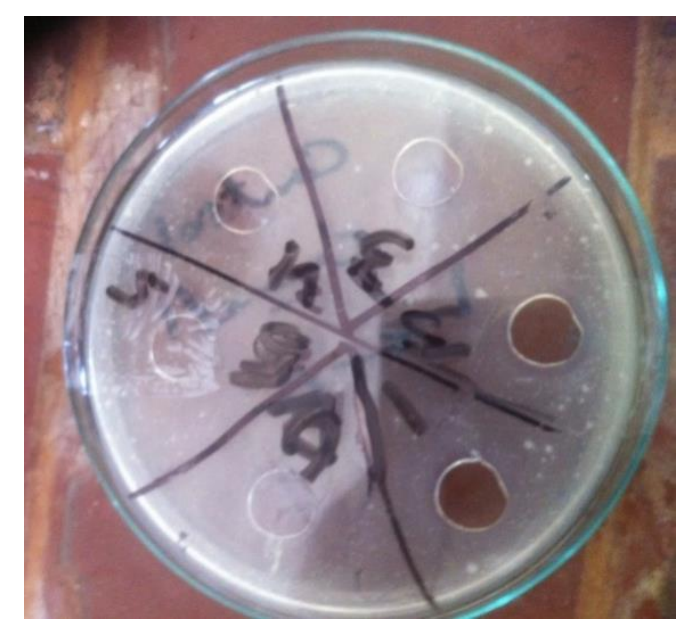

Figure (3): Diameters of inhibition zones $(\mathrm{mm})$ of Nigella sativa essential oil against isolated microorganisms

\section{Results for Effect of Additions Essential Oils on Isolated Microorganisms}

The microbial analysis to the different types of meat products showed that the minced meat was the largest contamination compared with the other products. The bacteriological load of meat mincing, sanitary conditions time and temperature of storage. The addition of thyme oil, garlic oil and nigella sative oil with concentration $0.5 \%, 0.75 \%$ and $1 \%$ done on the minced meat.

Microbiological evaluation of minced beef treated with thyme oil, garlic oil and black seeds oil.

Changes in total bacterial count of minced meat treated with essential oils during storage at $4^{\circ} \mathrm{c}$ for 20day:

Total bacterial counts have been used to assess sanitary quality, organoleptic ability, safety and utility of various meat products. The microbial activity leads to certain changes in flavor, color and accumulation of toxins in meat and its products (Flisset al., 1991).

Data presented in Table (4) pointed to the changes in total bacterial counts in minced meat samples formulated with essential oil of Thyme $0.5 \%$, Thyme $0.75 \%$, Thyme $1 \%$, Garlic $0.5 \%$. Garlic $0.75 \%$, Garlic $1 \%$ and black seeds $0.5 \%$, Nigellasativa $0.75 \%$, Nigellasativa $1 \%$ during storage at $4^{\circ} \mathrm{c}$ up to 20 day ranged between $6.6 \times 10^{8}$ and $2 \log$ $\mathrm{cfu} / \mathrm{gm}$ at end of storage periods. The table showed that the all treatment had positive effect on the growth of bacteria, the treatment of nigela was the highest effect when compared with other treatments on the other hand garlic treatment was the second while the thyme had effect but less than the other treatments.

On the other side, total bacterial counts for samples were lower than control sample was reached at the end of storage periods $4 \log c f u / g m$. Also, from these results, it could be observed that addition of essential oil at level 0.75 and $1 \%$ to the minced meat caused 
highest significant ( $\mathrm{p} \geq 0.05)$ decrease in total bacterial count, this decrease effect might be attributed to the effect of the antimicrobial compounds in these essential oils. Such findings are in agreement with those reported by (Pereira et al., 2004) who found that the essential oil of Nigella sativa has antibacterial activity due to the presence of 1.8-cineol compound.

Table (4): Changes in total bacterial count of minced meat treated with essential oils during storage at $4^{\circ} \mathrm{c}$ for 20 day

\begin{tabular}{|c|c|c|c|c|c|c|}
\hline \multirow{2}{*}{\multicolumn{2}{|c|}{ Treatments }} & \multicolumn{5}{|c|}{ Storage period (days) } \\
\hline & & $\mathbf{0}$ & 5 & 10 & 15 & 20 \\
\hline \multicolumn{2}{|c|}{ Control } & $6.6 \times 10^{8}$ & $8 \times 10^{8}$ & $8 \times 10^{8}$ & $10 \times 10^{8}$ & $3 \times 10^{8}$ \\
\hline \multicolumn{2}{|c|}{ Thyme $0.5 \%$, } & $8 \times 10^{8}$ & $6.45 \times 10^{8}$ & $5.36 \times 10^{7}$ & $5.89 \times 10^{6}$ & $6.36 \times 10^{6}$ \\
\hline \multicolumn{2}{|c|}{ Thyme $0.75 \%$} & $8 \times 10^{8}$ & $6.40 \times 10^{8}$ & $5.28 \times 10^{7}$ & $4.32 \times 10^{6}$ & $5.30 \times 10^{6}$ \\
\hline \multicolumn{2}{|c|}{ Thyme 1\% } & $8 \times 10^{8}$ & $6.35 \times 10^{8}$ & $5.44 \times 10^{7}$ & $6.40 \times 10^{6}$ & $7.43 \times 10^{6}$ \\
\hline \multicolumn{2}{|c|}{ Garlic $0.5 \%$} & $8 \times 10^{8}$ & $6.21 \times 10^{8}$ & $5.38 \times 10^{7}$ & $6.36 \times 10^{6}$ & $6.40 \times 10^{6}$ \\
\hline \multicolumn{2}{|c|}{ Garlic $0.75 \%$} & $8 \times 10^{8}$ & $6.21 \times 10^{8}$ & $5.27 \times 10^{7}$ & $6.15 \times 10^{6}$ & $5.38 \times 10^{6}$ \\
\hline \multicolumn{2}{|c|}{ Garlic $1 \%$} & $8 \times 10^{8}$ & $5.48 \times 10^{8}$ & $5.30 \times 10^{7}$ & $5.10 \times 10^{6}$ & $4.91 \times 10^{6}$ \\
\hline \multicolumn{2}{|c|}{ Black seeds $0.5 \%$} & $8 \times 10^{8}$ & $6.36 \times 10^{8}$ & $5.30 \times 10^{7}$ & $6.38 \times 10^{6}$ & $6.45 \times 10^{6}$ \\
\hline \multicolumn{2}{|c|}{ Black seeds $0.75 \%$} & $8 \times 10^{8}$ & $6.31 \times 10^{8}$ & $5.28 \times 10^{7}$ & $6.32 \times 10^{6}$ & $6.41 \times 10^{4}$ \\
\hline \multicolumn{2}{|c|}{ Black seeds $1 \%$} & $8 \times 10^{8}$ & $4.27 \times 10^{6}$ & $4.18 \times 10^{5}$ & $4.15 \times 10^{4}$ & $4.00 \times 10^{2}$ \\
\hline \multirow{3}{*}{ L.S.D 0.05} & $\mathbf{A}$ & \multicolumn{5}{|c|}{0.05} \\
\hline & B & \multicolumn{5}{|c|}{0.07} \\
\hline & $\mathbf{A B}$ & \multicolumn{5}{|c|}{0.17} \\
\hline
\end{tabular}

$\mathrm{A}=$ treatments (in the same column), $\mathrm{B}=$ storage period (in the same row), $\mathrm{AB}=$ Interaction

Changes in Psychrophilic bacterial count of minced meat treated with essential oils during storage at $4^{\circ} \mathrm{c}$ for 20 day:

Microorganisms which grow in food at refrigeration temperature have usually been called Psychrophilic. Many Psychrophilic bacteria when present in large numbers can cause a variety of off - flavors as well as physical and defects in foods (Gilliland et al., 1976).

From the obtained data in Table (5) it could be observed that, the Psychrophilic bacterial count in control sample was $6.30 \log 10 \mathrm{cfu} / \mathrm{gm}$ at zero time and significant $(\mathrm{p} \geq 0.05)$ increased to $10.77 \log 10 \mathrm{cfu} / \mathrm{gm}$ at the end of storage periods. Meanwhile, the psychrophilic bacterial count of samples contained essential oil of Thyme $0.5 \%$, Thyme $0.75 \%$, Thyme $1 \%$, Garlic $0.5 \%$. Garlic $0.75 \%$, Garlic $1 \%$ and black seeds $0.5 \%$, Nigella sativa $0.75 \%$, Nigella sativa $1 \%$ during storage at $4{ }^{\circ} \mathrm{c}$ up to 20 day had ranged from 6.3 to $3,32 \log 10 \mathrm{cfu} / \mathrm{gm}$ at the end of storage time, while at the end of storage period control sample shows changes in Psychrophilic bacterial count under the same condition. From the same Table it could be stated that minced meat samples treated with essential oils had little number of Psychrophilic bacterial count compared with control sample. On the other hand, 
the decreased rate of Psychrophilic bacterial count in minced beef samples treated with essential oil Nigella sativa $1 \%$ was higher than control sample during storage period at $4{ }^{\circ} \mathrm{c}$ for 20day, These results agree with those reported by (Abd EL - Hamied et al., 2009) they found that addition of Nigella sativa $1 \%$ to minced meathad inhibitory effect against Psychrophilic bacteria ascompared to the control sample. Also, (Oke et al. 2009) who stated that essential oils constitute a natural source of antimicrobial mixtures so essential oils and purified components are used as natural prevent the growth of food borne bacteria and molds antimicrobials in food systems, as well as to resulting in extension of the shelflife of processed foods.

Table (5): Changes in Psychrophilic bacterial count (log 10) of minced meat treated with essential oils during storage at $4^{\circ} \mathrm{c}$ for 20 day

\begin{tabular}{|c|c|c|c|c|c|c|}
\hline \multirow{2}{*}{\multicolumn{2}{|c|}{ Treatments }} & \multicolumn{5}{|c|}{ Storage period (days) } \\
\hline & & $\mathbf{0}$ & 5 & 10 & 15 & 20 \\
\hline \multicolumn{2}{|c|}{ Control } & 6.30 & 6.44 & 7.39 & 9.56 & 10.77 \\
\hline \multicolumn{2}{|c|}{ Thyme $0.5 \%$, } & 6.30 & 6.28 & 6.69 & 7.158 & 7.40 \\
\hline \multicolumn{2}{|c|}{ Thyme $0.75 \%$} & 6.30 & 6.00 & 6.30 & 6.49 & 6.90 \\
\hline \multicolumn{2}{|c|}{ Thyme $1 \%$} & 6.30 & 6.32 & 5.29 & 6.24 & 6.36 \\
\hline \multicolumn{2}{|c|}{ Garlic $0.5 \%$} & 6.30 & 5.96 & 5.11 & 5.00 & 4.83 \\
\hline \multicolumn{2}{|c|}{ Garlic $0.75 \%$} & 6.30 & 4.96 & 5.31 & 4.91 & 4.63 \\
\hline \multicolumn{2}{|c|}{ Garlic $1 \%$} & 6.30 & 6.32 & 6.00 & 5.24 & 5.10 \\
\hline \multicolumn{2}{|c|}{ Black seeds $0.5 \%$} & 6.30 & 5.63 & 5.81 & 5.158 & 4.91 \\
\hline \multicolumn{2}{|c|}{ Black seeds $0.75 \%$} & 6.30 & 5.10 & 4.83 & 4.55 & 4.36 \\
\hline \multicolumn{2}{|c|}{ Black seeds $1 \%$} & 6.30 & 5.43 & 4.93 & 4.66 & 3.32 \\
\hline \multirow{3}{*}{ L.S.D 0.05} & $\mathbf{A}$ & \multicolumn{5}{|c|}{0.07} \\
\hline & B & \multicolumn{5}{|c|}{0.09} \\
\hline & $\mathbf{A B}$ & \multicolumn{5}{|c|}{0.22} \\
\hline
\end{tabular}

Changes in E.COLI counts of minced meat treated with essential oils during storage at $4^{\circ} \mathrm{c}$ for 20 day:

Although the total bacterial count was used in bacteriological examination to reflect the hygienic quality, however, it is evident that coliform group count is considered of much greater value in assessing its quality (Cruickshank et al., 1975) and Pasqa (2005).

From the obtained data in Table (6)it was found that control sample had significantly $(\mathrm{p} \geq$ 0.05) difference the higher counts E.coli when compared to other treatments which formulated with essential oils at levels 0.50 and $0.75 \%$ and $1 \%$ at zero time and at end of storage periods. Essential oil of Nigella sativa at level $1 \%$ was more active of inhibiting effect against coliform group bacteria which disappear after 10days of storage period 
compared with other essential oils. Also, from the same Table, it could be noticed that $E$. Coligroup disappear in most minced meat samples formulated with essential oil at levels $1 \%$ 10,15 days. These results indicated that the essential oils at both concentrations inhibited the growth of E.Coligroup bacteria. These results are similar as mentioned by (Farag et al., 1989 and Mahamed, E.A. 2013). They tested the essential oils of some essential oils for their inhibitory effect against three Gram-negative bacteria (Pseudomonas fluorescens, Escherichia coli, and Serratia marcescens) and four Gram-positive bacteria (Staphylococcus aureus, Micrococcus spp., Saracina spp. and Bacillus subtilis).

Table (6): Changes in E.COLI count of minced meat treated with essential oils during storage at $4^{\circ} \mathrm{c}$ for 20 day

\begin{tabular}{|c|c|c|c|c|c|c|}
\hline \multirow{2}{*}{\multicolumn{2}{|c|}{ Treatments }} & \multicolumn{5}{|c|}{ Storage period (days) } \\
\hline & & $\mathbf{0}$ & 5 & 10 & 15 & 20 \\
\hline \multicolumn{2}{|c|}{ Control } & $6 \times 10^{2}$ & $6.4 \times 10^{2}$ & $6 \times 10^{4}$ & $6.5 \times 10^{4}$ & $8 \times 10^{4}$ \\
\hline \multicolumn{2}{|c|}{ Thyme $0.5 \%$, } & $6 \times 10^{2}$ & $6.2 \times 10^{2}$ & $6.68 \times 10^{2}$ & $7 \times 10^{2}$ & $7 \times 10^{2}$ \\
\hline \multicolumn{2}{|c|}{ Thyme $0.75 \%$} & $6 \times 10^{2}$ & $6 \times 10^{2}$ & $6.30 *$ & $6.49 *$ & $6^{*}$ \\
\hline \multicolumn{2}{|c|}{ Thyme 1\% } & $6 \times 10^{2}$ & $6.3 \times 10^{2}$ & $5.29 *$ & 0.00 & 0.00 \\
\hline \multicolumn{2}{|c|}{ Garlic $0.5 \%$} & $6 \times 10^{2}$ & $4.4 \times 10^{2}$ & $4.1 \times 10^{2}$ & $4 \times 10^{2}$ & $3 \times 10^{2}$ \\
\hline \multicolumn{2}{|c|}{ Garlic $0.75 \%$} & $6 \times 10^{2}$ & $4.9 \times 10^{2}$ & $4.31 *$ & $3.91 *$ & $3.00 *$ \\
\hline \multicolumn{2}{|c|}{ Garlic $1 \%$} & $6 \times 10^{2}$ & $6.3 \times 10^{2}$ & $4.00 *$ & 0.00 & 0.00 \\
\hline \multicolumn{2}{|c|}{ Black seeds $0.5 \%$} & $6 \times 102$ & $5.6 \times 10^{2}$ & $5.2 \times 10^{2}$ & $5 \times 10^{2}$ & $4 \times 10^{2}$ \\
\hline \multicolumn{2}{|c|}{ Black seeds $0.75 \%$} & $6 \times 10^{2}$ & $5.5 \times 10^{2}$ & $4.83^{*}$ & 0.00 & 0.00 \\
\hline \multicolumn{2}{|c|}{ Black seeds $1 \%$} & $6 \times 10^{2}$ & $4 \times 10$ & 0.00 & 0.00 & 0.00 \\
\hline \multirow{3}{*}{ L.S.D 0.05} & $\mathrm{~A}$ & \multicolumn{5}{|c|}{0.07} \\
\hline & $\mathrm{B}$ & \multicolumn{5}{|c|}{0.09} \\
\hline & $\mathrm{AB}$ & \multicolumn{5}{|c|}{0.22} \\
\hline
\end{tabular}

$\mathrm{A}=$ treatments (in the same column), $\mathrm{B}=$ storage period (in the same row), $\mathrm{AB}=$ Interaction $*=\log$ 10

Changes in Salmonella counts of minced meat treated with essential oils during storage at $4^{\circ} \mathrm{c}$ for 20 day:

Salmonella is now established, as one of the most important causes of food - brone illness at world wide (D Aoust. 1989) and Hussien (1994).

From the obtained data in Table (7) it was found that control sample had significantly $(\mathrm{p} \geq$ 0.05) difference the higher counts Salmonella when compared to other treatments which formulated with essential oils at levels 0.50 and $0.75 \%$ and $1 \%$ at end of storage periods. Essential oil of black seeds at level $1 \%$ was more active of inhibiting effect against Salmonella group bacteria which disappear after 5 days of storage period compared with other essential oils. Also, from the same Table, it could be noticed that Salmonella group disappear in most minced beef samples formulated with essential oil at levels $0.75 \%$ and 1 $\%$ after 10,15 days. These results indicated that the essential oils at both concentrations inhibited the growth of Salmonella group bacteria. all minced beef samples contained 
essential oils were completely free from Salmonella which means that the minced beef samples contained essential oils were prepared under hygienic condition. These results agree those obtained by (Stock and Stolle 2001) examined 1485 minced meat samples collected from European Union (EU) throughout 21 months for presence of Salmonella. 93 samples $(6.3 \%)$ were proved to be contaminated with Salmonellae, and the microbial qualities of these samples were somewhat deficient. (Ismail and Belma 2002) investigated 35 frozen meat samples commercially marketed in Izmir for determining the microbiological quality. They isolated 28 Salmonella spp. From the examined sample with a rate of $80 \%$ (Soliman et al. 2002) examined 120 ready to eat samples for microbiological quality in urban and rural area. They could not isolate Salmonella from beef burger in urban areas; in contrary to rural areas they could isolate Salmonella spp. from $10 \%$ of the exam beef-burger samples.

Zhao et al. (2002) conducted a research to determine the prevalence of Salmonella typhimurium in ground beef. Salmonella species were isolated from 14 (3.5\%) samples.

Badrie et al. (2003) examined 27 samples of hamburger for the presence of food borne pathogens and found that $18.5 \%$ of samples were positive for Salmonella. On contrary to those Chung et al. (2003) they could not isolate salmonella from any tested hamburger samples. Wehab and Aideia (2002) planned an investigation to determine the quality of market different types of luncheon meat samples collected from Giza and Cairo. They failed to detect any Salmonella species from any examined sample.

Table (7): Changes in Salmonella counts of minced beef treated with essential oils during storage at $4^{\circ} \mathrm{c}$ for 15 day

\begin{tabular}{|c|c|c|c|c|c|c|}
\hline \multirow{2}{*}{\multicolumn{2}{|c|}{ Treatments }} & \multicolumn{5}{|c|}{ Storage period (days) } \\
\hline & & $\mathbf{0}$ & 5 & 10 & 15 & 20 \\
\hline \multicolumn{2}{|c|}{ Control } & $2.3 \times 10^{2}$ & $3.4 \times 10^{2}$ & $5.4 \times 10^{2}$ & $7.1 \times 10^{4}$ & $8.7 \times 10^{4}$ \\
\hline \multicolumn{2}{|c|}{ Thyme $0.5 \%$, } & $2.3 \times 10^{2}$ & $2.3 \times 10^{2}$ & $2.1 \times 10^{2}$ & $2 \times 10^{2}$ & $2 \times 10^{2}$ \\
\hline \multicolumn{2}{|c|}{ Thyme $0.75 \%$} & $2.3 \times 10^{2}$ & $2.2 \times 10^{2}$ & $2.1 \times 10^{2}$ & $2.1 *$ & 0.00 \\
\hline \multicolumn{2}{|c|}{ Thyme $1 \%$} & $2.3 \times 10^{2}$ & $3 \times 10^{2}$ & $2.1 *$ & 0.00 & 0.00 \\
\hline \multicolumn{2}{|c|}{ Garlic $0.5 \%$} & $2.3 \times 10^{2}$ & $2.3 \times 10^{2}$ & $2.2 \times 10^{2}$ & $2.1 \times 10^{2}$ & $2 \times 10^{2}$ \\
\hline \multicolumn{2}{|c|}{ Garlic $0.75 \%$} & $2.3 \times 10^{2}$ & $2.2 \times 10^{2}$ & $2.1 \times 10^{2}$ & $2.00 *$ & 0.00 \\
\hline \multicolumn{2}{|c|}{ Garlic $1 \%$} & $2.3 \times 10^{2}$ & $2,20^{*}$ & 0.00 & 0.00 & 0.00 \\
\hline \multicolumn{2}{|c|}{ Black seeds $0.5 \%$} & $2.3 \times 10^{2}$ & $2.9^{*}$ & $2.11^{*}$ & 0.00 & 0.00 \\
\hline \multicolumn{2}{|c|}{ Black seeds $0.75 \%$} & $2.3 \times 10^{2}$ & $2.10^{*}$ & 0.00 & 0.00 & 0.00 \\
\hline \multicolumn{2}{|c|}{ Black seeds $1 \%$} & $2.3 \times 10^{2}$ & 0.00 & 0.00 & 0.00 & 0.00 \\
\hline \multirow{3}{*}{ L.S.D 0.05} & $\mathbf{A}$ & \multicolumn{5}{|c|}{0.07} \\
\hline & $\mathbf{B}$ & \multicolumn{5}{|c|}{0.09} \\
\hline & $\mathbf{A B}$ & \multicolumn{5}{|c|}{0.22} \\
\hline
\end{tabular}

$\mathrm{A}=$ treatments (in the same column), $\mathrm{B}=$ storage period (in the same row), $\mathrm{AB}=$ Interaction $*=\log 10$

Changes in Staphylococcus aureus counts of minced meat treated with essential oils during storage at $4^{\circ} \mathrm{c}$ for 20 day: 
The Staphylococcal genus contains at least 23 species, most important being Staphylococcus aureus. This organism is of major concern to the meat and poultry industries (Miller et al., 1997) .

Staphylococcal food poisoning (SFP) is an intoxication that results from the consumption of foods containing sufficient of one or more preformed enterotoxin, symptoms of SFP have a rapid onset (2-8h), and include nausea, violent vomiting and abdominal cramping with or without diarrhea (Dinges et al., 2000).

The disease is usually self-limiting and typically resolves with in 24-48 h after onset. Occasionally it can be severe enough to warrant hospitalization, particularly when infants, elderly or debilitated people are concerned (Batabyal et al., 2012).

Data given in Table (8) show the Staphylococcus aureus counts in different minced meat contained essential oil of black seeds $0.5 \%$, black seeds $0.75 \%$, black seeds $1 \%$, Garlic $0.5 \%$ Garlic $0.75 \%$, Garlic $1 \%$ and Thyme $0.5 \%$, Thyme $0.75 \%$, Thyme $1 \%$ during storage at $4^{\circ} \mathrm{C}$ up to 20 day. These results showed that Staphylococcus aureus counts increased in control sample so, the Staphylococcus aureus counts at zero time was3.3 log cfu/gm and at the end of storage period reached to $5.15 \log \mathrm{cfu} / \mathrm{gm}$. From the same Table, it could be noticed that Staphylococcus aureus counts significant $(\mathrm{p} \geq 0.05)$ decreased during storage time in minced sample contained essential oil of Nigella sativa at level 0.75 and $1 \%$. Staphylococcus aureus counts for these samples were less than the control sample. Meanwhile, after storage for 5 days Staphylococcus aureus disappeared in minced beef samples contained Nigellasativa essential oil at level 1\%. Also, it disappeared in samples contained essential oil at level0.50\%. The disappearing of Staphylococcus aureus may be attributed to antimicrobial activity of these essential oils Abd El- Qader, (2003), A. Latif and Ibraheem (1996), Hussain and Tobji (1997).

Table (8): Changes in Staphylococcus aureus counts of minced meat treated with essential oilsduring storage at $4^{\circ} \mathrm{c}$ for 20 day

\begin{tabular}{|c|c|c|c|c|c|c|}
\hline \multirow{2}{*}{\multicolumn{2}{|c|}{ Treatments }} & \multicolumn{5}{|c|}{ Storage period (days) } \\
\hline & & $\mathbf{0}$ & 5 & 10 & 15 & 20 \\
\hline \multicolumn{2}{|c|}{ Control } & $3.3 \times 10^{2}$ & $3.9 \times 10^{2}$ & $4.2 \times 10^{2}$ & $4 \times 10^{3}$ & $5.4 \times 10^{3}$ \\
\hline \multicolumn{2}{|c|}{ Thyme $0.5 \%$, } & $3.3 \times 10^{2}$ & $3.2 \times 10^{2}$ & $3.1 \times 10^{2}$ & $3 \times 10^{2}$ & $2.4 \times 10^{2}$ \\
\hline \multicolumn{2}{|c|}{ Thyme $0.75 \%$} & $3.3 \times 10^{2}$ & $3.2 \times 10^{2}$ & $3.1 \times 10^{2}$ & $3.11 *$ & $2.69 *$ \\
\hline \multicolumn{2}{|c|}{ Thyme $1 \%$} & $3.3 \times 10^{2}$ & $3 \times 10^{2}$ & $2.41 *$ & 0.00 & 2.00 \\
\hline \multicolumn{2}{|c|}{ Garlic $0.5 \%$} & $3.3 \times 10^{2}$ & $3.2 \times 10^{2}$ & $3.1 \times 10^{2}$ & $3 \times 10^{2}$ & $2 \times 10^{2}$ \\
\hline \multicolumn{2}{|c|}{ Garlic $0.75 \%$} & $3.3 \times 10^{2}$ & $3.2 \times 10^{2}$ & $2.1 \times 10^{2}$ & $2.00 *$ & 0.00 \\
\hline \multicolumn{2}{|c|}{ Garlic $1 \%$} & $3.3 \times 10^{2}$ & $2.1 \times 10^{2}$ & $2.00 *$ & 0.00 & 0.00 \\
\hline \multicolumn{2}{|c|}{ Black seeds $0.5 \%$} & $3.3 \times 10^{2}$ & $2.5 \times 10^{2}$ & $2.1 \times 10^{2}$ & $2.05^{*}$ & 0.00 \\
\hline \multicolumn{2}{|c|}{ Black seeds $0.75 \%$} & $3.3 \times 10^{2}$ & $2.25^{*}$ & $2.00 *$ & 0.00 & 0.00 \\
\hline \multicolumn{2}{|c|}{ Black seeds $1 \%$} & $3.3 \times 10^{2}$ & 0.00 & 0.00 & 0.00 & 0.00 \\
\hline \multirow{3}{*}{ L.S.D 0.05} & $\mathbf{A}$ & & & & & \\
\hline & B & \multicolumn{5}{|c|}{0.10} \\
\hline & $\mathbf{A B}$ & \multicolumn{5}{|c|}{0.24} \\
\hline
\end{tabular}

$* \mathrm{~A}=$ treatments (in the same column), $\mathrm{B}=$ storage period (in the same row), $\mathrm{AB}=$ Interaction 


\section{References}

- A.P.H.A. (1976). American public Health Association of Methods for the Microbiological Examination of Foods. Speck, M. L. ed., Washington, D. C., USA.

- Alatif, A and Ibrabeem, O.K. (1996) studies on the effect of Hibiscus Subdriffa, Allium Sativum and Nnegilla sativa on some bacteria isolated of chicken. $7^{\text {th }}$. Sci. Cong. 17-19Nov.1996, Fac. Vet. Med, Assiut, Egypt.

- Abd El-Hamied, A. A.;Nassar, A. G. and El-Badry, N. (2009). Investigations on antioxidant and antimicrobial activities of some natural extracts. World Journal of Dairy Food Sciences, 4: 01- 07.

- Abd El-Qader, M. F. (2003). Quality improvement of chicken frozen burger formulated with some spices or their volatile oils. M. Sc. Thesis. Fac. of Agric. Cairo Univ., Egypt.

- Ahmed, Z.: Mehrdad, I.; Shahabodin, G. and Zahra, R. (2011). Investigation of antibacterial effects of garlic (Allium sativum), Mint (Mentha spp.) and onion (Allium cepa) herbal extracts on Escherichia coli isolated from broiler chickens. African Journal ofBiotechnology, 10: (50), 10320-10322.

- Ankri, S. and D. Mirelman,(1999). Antimicrobial properties of allicin from garlic. Microbes Infect, 1: 125-129.

- Ayaz, E. and H.C. Alpsoy, 2007. Garlic (Allium sativum) and traditional medicine. ActaParasitol. Turcica, 31: 145-149.

- Badrie, N., Joseph, A. and Chen, A. (2003). An observational study of food safety practices street vendors and microbiological quality of street-purchased hamburger beef patties in Trinidad. West Indies. Internet. Journal of Food safety, 3:25-31.

- Batabylal. B, Kundu.G and Brswas.S (2012). Methicillin-Resistant Staphylococcus aureus. A Briat Review. International research, Journal of Biological Sciences $1(7) 65-71$.

- Baytop, T., (1999). The Treatment Plant in Turkey. Nobel Tip Kitabevi Istanbul, ISBN: 9754200211.

- Burt, S. (2004). Essential oils: Their antibacterial properties and potential applications in foods -A review. International Journal of Food Microbiology, 94: 223-253.

- Burits, M. and Bucar, F. (2000). Antioxidant activity of Nigella sativa essential oil. Phytotherapy Research, 14: 323-328. 
- Brul, S. and Coote, P. (1999). Review: Preservative agents in foods: mode of action and microbial resistance mechanisms. International Journal Food Microbiology, 50:1-17.

- Celiini, L., B. Di Campli, M. Masulli, S. Di Bartolomeo and N. Aliocati, (1996). Inhibition of Helicobacter pylori by Garlic extract. FEMS Immenol. Med. Micrbiol., 13: 273-277.

- Chung, Y.H., Kim, S.Y. and Chang.Y.H. (2003). Prevalence and antibiotic susceptibility of salmonella isolated from foods in Korea from 1993 to 2001. Journal of Food Protection, 66(7):1154-1157.

- Cruickshank, R.;Duguid, J. P. and Swain, R. A. (1975). Medical Microbiol, 12 end. Vol 2, E. S., livingston limited Edinburg London and New York.

- D'Aoust, J. Y. (1989). Salmonella in: Food borne Bacterial Pathogens, Doyle, M. P. ed., PP. 327-445-New York Makel Dekker.

- Dinges. MM, Orwin.PM andSchlievert PM (2000). Exotoxins of staphylococcus aureus, Clinical Microbiology Review 13:16-34.

- Domokos, J.; Hethelyi, E.; Palinkas, J.; Szirmai, and tulok, M. H. (1997). Essential oil of rosemary (Rosmarinus officinalis) of Hungarian origin. Journal of Essential Oil Research, 9: 41-45.

- Detz, V.; McCaig, L.F.; Breese, J.S.; Shapiro, C.; Griffin, P.M. and Tauxe, R.V. (1999). Food related illness and dead in the United States. Emerging Infectious Diseases 5: 607-625.

- Difco-Manual, (1984). Dehydrated culture media and reagents microbiological and clinical laboratory procedures, Pub-Difco-Lab-Detroits Michigan, USA.

- FAO, (1979). Manuals of food-quality controls, 4, microbiological analysis. Food and Agriculture organization of the united nations. Rome, PP. C9-12 and DI-33.

- Farag, R. S.; Daw, Z. Y.; Hewedi, F. M. and El-Baroty, G. S. A. (1989). Antimicrobial activity of some Egyptian spice essential oils. Journal of Food Protection, 52: 665-667.

- FazlyBazzaz, B.S. Hosseinzadeh, H. and MotevalyHaghi, M. (2002) Antibacterial activity of total extracts and essential oil of Nigella sativa seedson mice. Pharm. Pharmacol. J.54.

- Flis-s, L.;Sinard, R. and Ltkiki, A. (1991). Composition of three sampling techniques for microbiological analysis of meat science. Journal Food Science, 56: 249. 
- Friedman, M.;Henika, P.R. and Mandrell, R.E. (2002). Bactericidalactivities of plant essential oils and some of their isolated constituents against Campylobacter jijunu, Escherichia coli, Listeria monocytogenes and Salmonella enterica. Journal of Food Protection 65, 1545-1560.

- Geldof, N. and Engeseth, N.J. (2002). Antioxidant capacity of honeys from various floral sources based on the determination of oxygen radical absorbance capacity and inhibition of in vitro lipoprotein oxidation in human serum samples. Journal Agricultural and Food Chemistry, 50: 3050-3055.

- Gilliland, S.E.; Michener, H.D. and Kraft, A.A. (1976). Psychrotrophic microorganisms. In: Compendium of Methods of Microbiological Examination of food, speek, M. L. ed., pp. 173-178. American public health Association, Inc. Washington, D.C., USA.

- Hussain. H. and Tobji, R.S. (1997) Antibacterial screening of some Libyan medicinal plant. Fitoterapia 68(5):467-470.

- Ismail, K. and Belma. (2002). Microbiological investigations on some of the commercial frozen meat in Izmer. Turkish electronic Journal of Biotechnology. pp.18-23.

- Lemar, K.M., O. Passa, M.A. Aon, S. Cortassa and C.T. Muller et al., (2005). Allyl alcohol and garlic (Allium sativum) extract produceoxidative stress in Candida albicans. Microbiology, 151:3257-3265.

- Lopez, P.; Sanchez, C.; Battle, R. and Nerin, C. (2005). Solid- and vapor-phase antimicrobial activities of six essential oils: susceptibility of selected food borne bacterial and fungal strains. Journal of Agricultural and Food Chemistry, 53: 69396946.

- Mahmoud, E. A. (2013) Studies on improvement shelf life and safety of minced beef with some spices or their volatile oils THESIS Submitted in Partial Fulfillment of the requirements for the degree of doctor of philosophy. Faculty of Agriculture, Al-Azhar University (Assiut).

- Marino M, Bersani C, Comi G (2001) Impedance measurements to study the antimicrobial activity of essential oils from Lamiaceae and Compositae. Int J Food Microbiol 67: 187-195.

- Morsi, N. M. (2000). Antimicrobial effect of crude extracts of Nigella sativa on multiple antibiotics-resistant bacteria. Acta Microbiologica Polonica, 49: 63-74.

- Miller, A. J.; Ackerman, S. A. and Palumbo, S. A. (1989). Effect of frozen storage on functionally of meat for processing. Journal Food Science, 45(3): 1466. 
- Oke F, Aslim B, Ozturk S, Altundag S (2009) Essential oil Composition antimicrobial and antioxidant activities of SaturejacuneifoliaTen. Food Chem 112: 874- 879 .

- Pasqa, R. D. I.; Feo, V. D. E.; Villani, F. and Mauriello, G. (2005). In vitro antimicrobial activity of essential oils from Mediterranean Apiaceae, Verbenaceae and Lamiaceae against foodborne pathogens. Annals of Microbiology, 55(2): 139143.Troy, D. J. and Kerry, J. P. (2010). Consumer perception and the role of science in the meat industry. Meat Science, 86: 214-226.

- Sayed, A.M., Abou El-Alla, AbdElhafeez, Hussein, A.A. and Hassanein, Z.A. (2001). Prevalence of E.coli with special reference to E.coli 0157:H7 insome retail meat products and cattle in Assiut Governorate. Assiut Vet.Med. J., 45(90):146156.

- Stock, K. and Stolle, A. (2001). Incidence of Salmonella in Minced meat products in European Union-approved cutting plant. Journal of Food Protection, 64(9)14351438.

- Soliman, M.R., Abdel Monem, K.M. and Saad, S.M. (2002) Microbiological quality of ready-to-eat meat products and fishes in Urban and rural areas, J. Egypt. Vet. Med. Ass.62(6a):39-51.

- Tiwari, B.K.; Valdramidis, V. P.; O’Donell, C.P.; Muthukumarappan, K.; Bourke, P. and Cullen. PJ. (2009). Application of natural antimicrobials for food preservation. Journal Agricultural and Food Chemistry, 57: 5987-6000.

- Wehab, H.H. and Aideia, A.M. (2002). Chemical and bacteriological studies on different types of luncheon. J. Egypt Vet. Med. Ass., 62(6)103-112.

- Yoshida, H., N. Iwanta, H. Katsuzaki, R. Naganawa and K. Ishikawa et al., (1998). Antimicrobial activity of a compound isolatedfrom an oil-macerated garlic extract. Biosci. Biotechnol. Biochem62: 1014-1017.

- Zhao, Y.; Wells, J. H. and McMillin, K. W. (1994). Applications of dynamic modified atmosphere packaging systems for fresh red meats - Review. Journal of Muscle Foods, 5: 299-328. 